\title{
RESPON MAHASISWA TERHADAP PERKULIAHAN ONLINE PADA PEMBELAJARAN MATEMATIKA DI MASA PANDEMI COVID-19
}

\author{
Lisnani $^{1}$, Benidiktus Tanujaya ${ }^{2}$ \\ Universitas Katolik Musi Charitas, Jl. Bangau No.60, 9 Ilir, Palembang, Indonesia ${ }^{1}$ \\ Universitas Papua, Jl. Gunung Salju, Amban, Manokwari Barat, Indonesia ${ }^{2}$ \\ E-mail: lisnani@ukmc.ac.id
}

\begin{abstract}
Abstrak
Pandemi COVID-19 telah merubah sistem pendidikan di Indonesia termasuk di perguruan tinggi. Perkuliahan tatap muka diharuskan menjadi pembelajaran system online pada semua mata kuliah, termasuk pada pembelajaran matematika. Penelitian ini bertujuan untuk menganalisis respon mahasiswa terhadap perkuliahan online di masa pandemi Covid-19. Penelitian menggunakan metode penelitian kualitatif deskriptif, dengan 30 mahasiswa peserta kuliah matematika kelas tinggi sebagai subjek penelitian. Pengumpulan data dilaksanakan melalui kegiatan analisis dokumen, observasi, dan wawancara menggunakan kuesioner. Data kemudian dianalisis dengan analisis statistika deskriptif berupa diagram dan disajikan dalam bentuk narasi. Hasil penelitian menunjukkan bahwa proses perkuliahan online berbentuk penggunaan platform digital, sebagian besar berupa video conference via zoom, cloud meeting, WhatsApp, dan Lumen milik Universitas. Mayoritas mahasiswa tidak menyukai perkuliahan online, walaupun penyampaian materi selama perkuliahan online tidak jauh berbeda dengan perkuliahan tatap muka. Dua alasan utama mereka tidak menyukai perkuliahan online adalah kualitas jaringan internet yang tidak stabil dan kesulitan memahami materi kuliah.
\end{abstract}

Kata Kunci: Covid-19, pembelajaran online, pembelajaran matematika, respon mahasiswa

\begin{abstract}
The COVID-19 pandemic has significantly changed Indonesia's educational system, including its universities. In all subjects, including mathematics, face-to-face learning systems must be transformed into online learning systems. The purpose of this study is to examine student responses to online lectures delivered during the Covid-19 pandemic. The study employed a descriptive qualitative method, with 30 students enrolled in high-grade mathematics courses. The data collection process included document analysis, observation, and questionnaire-assisted interviews. After that, the data were analyzed using descriptive statistics techniques and presented in diagrams and narration. The results revealed that the online lecture process incorporated a digital platform, including video conferencing via Zoom, cloud meetings, WhatsApp, and the University's Lumen. The majority of students dislike online learning, even though the lectures are delivered like face-to-face lectures. They dislike online courses for two primary reasons: the unstable quality of the internet network and difficulty comprehending subject concepts.
\end{abstract}

Keywords: Covid-19, online learning, mathematics learning, student response

\section{PENDAHULUAN}

Kasus pertama Covid-19 di Indonesia menimpa dua warga Depok, Jawa Barat diumumkan langsung oleh Presiden Joko Widodo di Istana Kepresidenan, Jakarta pada 
tanggal 2 Maret 2020 (Ihsanuddin, 2020). Sejak tanggal tersebut, kasus penderita positif COVID-19 di Indonesia terus meningkat. Virus COVID-19 menyerang puluhan hingga ribuan orang sekaligus menyebabkan kematian sejumlah pendudukan di Indonesia. Peningkatan jumlah penderita dan kematian karena virus ini juga terjadi di seluruh dunia. Keadaan tersebut menyebabkan UNESCO (United Nations Educational, Scientific and Cultural Organization) menetapkan kebijakan social distancing/physical distancing (menjaga jarak fisik) untuk memutus mata rantai penularan virus COVID-19.

Pada bidang Pendidikan, UNESCO pada 4 Maret 2020 menyarankan penggunaan pembelajaran jarak jauh dan membuka platform pendidikan yang dapat digunakan sekolah dan guru untuk menjangkau peserta didik. Lebih lanjut dilaporkan bahwa pada 13 April 2020, terdapat sebanyak 191 negara telah menerapkan penutupan nasional yang berdampak kepada 1.575.270.054 siswa atau sekitar 91.3\% dari populasi siswa dunia (UNESCO, 2020). Sehubungan dengan kebijakan tersebut, Pemerintah Indonesia, melalui Kementerian Pendidikan dan Kebudayaan turut mengambil kebijakan sebagai panduan dalam menghadapi penyakit tersebut di tingkat satuan pendidikan (Kemdikbud, 2020).

Salah satu respon yang muncul dari kebijakan Kemdikbud yaitu kebijakan belajar di rumah melalui pembelajaran daring (online learning) bagi siswa atau mahasiswa dan guru atau dosen (Khairanisyam, 2020). Kebijakan ini tentunya membuat seluruh elemen yang terlibat di bidang pendidikan baik itu guru, siswa, orang tua, dosen dan mahasiswa merasa kaget kendatipun pembelajaran online sudah berlangsung sejak beberapa tahun terakhir tapi tidak secara utuh dalam bentuk blended learning di beberapa perguruan tinggi baik (McGee \& Poojary, 2020; Shamsuddin \& Kaur, 2020). Akan tetapi, sejak pandemi Covid-19, perkuliahan online berlangsung secara berkesinambungan.

Perkuliahan online atau yang biasa disebut pembelajaran daring merupakan salah satu bentuk pemanfaatan internet yang dapat meningkatkan peran mahasiswa dalam proses pembelajaran. Guna mempermudah proses pembelajaran online, akitivitas mahasiswa dan dosen difasilitasi dengan berbagai platform digital seperti video conference (Zoom, Google Meet, Skype, Webex), google classroom, dan berbagai Learning Management System (LMS). Menurut Tanujaya, et al. (2021), LMS merupakan salah satu Platform digital yang banyak digunakan untuk perkuliahan online di perguruan tinggi. Lebih lanjut Aldiab, et al., (2018), menyatakan bahwa LMS merupakan perangkat 
lunak yang mengotomatiskan administrasi kegiatan pembelajaran. LMS dapat digunakan untuk mendaftarkan pengguna, melacak pembelajaran dalam katalog, mencatat data dari peserta didik, dan menyediakan laporan kepada manajemen pengelolanya.

LMS merupakan salah satu platform pembelajaran online yang digunakan Universitas Katolik Musi Charitas, termasuk di program studi PGSD. Penggunaan LMS sebenarnya bertujuan untuk pembelajaran online di Universitas Katolik Musi Charitas lebih terintegrasi dan terkontrol. Untuk maksud tersebut, maka pihak universitas memfasilitasi dosen dengan LMS dalam bentuk Moodle. Platform pembelajaran online ini dikembangkan sendiri oleh universitas dan diberi nama Lumen Universitas Katolik Musi Charitas.

Moodle merupakan salah satu LMS bersifat open source berbasis web yang dibangun berdasarkan filosofi pendidikan yang sehat dengan maksud untuk mendukung kegiatan pengajaran. LMS ini dapat diunduh atau dimodifikasi oleh siapa saja karena menggunakan GNU - General Public License (Mtebe, 2015). Moodle juga sering disebut sebagai sebagai sumber daya LMS untuk lingkungan belajar atau Virtual Learning Environments (VLEs) yang dibagi menjadi tiga system, yaitu: perangkat keras, berupa mesin yang menggerakkan perangkat lunak Moodle seperti komputer, laptop, ponsel pintar, dan mesin digital lainnya, perangkat lunak, yang menampilkan informasi dari perangkat keras, dan perlengkapan ideologis (pendekatan/teori/visi atau visi pendidikan/kurikulum) (Khoza, 2014).

Lebih lanjut, diketahui bahwa perkuliahan online sebenarnya bertujuan untuk mempermudah dosen dalam pemberian pemberian materi (mengunggahnya), memberi tugas dan mengadakan tes. Pembelajaran online juga mendorong mahasiswa menjadi makin kreatif, mandiri dan disiplin dalam belajar (Sukarno, 2014). Namun agar pembelajaran online dapat berlangsung dengan baik dan berkesinambungan, maka perlu diketahui kelebihan dan keterbatasan masing-masing platform yang digunakan dalam perkuliahan. Kelebihan dan keterbatasan suatu platform pembelajaran online dapat diketahui melalui penelitian terhadap respon yang ditampilkan oleh mahasiswa sebagai pengguna.

Penelitian tentang pembelajaran online sudah dilakukan beberapa peneliti mulai dari menganalisis persepsi, keuntungan, kendala, solusi, dan efektivitas pembelajaran online di berbagai tingkatan baik di sekolah maupun di perguruan tinggi (Erin \& 
Maharani, 2018; Handayani, 2020; Firman \& Rahman, 2020; Widiyono, 2020). Namun penelitian tentang pembelajaran online di Universitas Katolik Musi Charitas, belum pernah dilakukan. Respon mahasiswa terhadap pembelajaran online perlu diketahui untuk memberikan solusi terhadap permasalahan, memperbaiki yang salah, meningkatkan yang kurang baik, dan mempertahankan yang sudah baik. Tanujaya, et al., (2021), menyatakan bahwa dengan memahami permasalahan yang dihadapi dalam pembelajaran online, pemerintah dan stakeholder pendidikan lainnya, termasuk universitas, sehingga dapat mengambil berbagai langkah startegis untuk meningkatkan kualitas perkuliahan.

Oleh karena itu, peneliti ingin memperoleh informasi tentang respon mahasiswa terhadap perkuliahan online pada pembelajaran matematika, khususnya pada mata kuliah Pembelajaran Matematika Kelas Tinggi. Pembelajaran Matematika Kelas Tinggi merupakan mata kuliah lanjutan dari Pembelajaran Matematika Kelas Rendah. Mata kuliah ini berhubungan dengan konsep dan perhitungan yang biasanya dipelajari secara luring (tatap muka) bukan secara daring (online). Oleh karena itu, Pembelajaran Matematika Kelas Tinggi merupakan mata kuliah yang semakin sulit untuk dipahami oleh mahasiswa apalagi pembelajaran dilakukan secara online. Informasi yang ingin diperoleh dalam penelitian ini berkaitan dengan proses pelaksanaan perkuliahan online, platform digital yang digunakan, dan kendala yang dihadapi selama proses perkuliahan online.

Dengan demikian, penelitian ini bertujuan untuk memperoleh informasi tentang respon mahasiswa selama proses perkuliahan online, khususnya pada mata kuliah Pembelajaran Matematika Kelas Tinggi pada mahasiswa semester III Program Studi PGSD Universitas Katolik Musi Charitas. Hasil penelitian diharapkan dapat menjadi bahan masukkan kepada berbagai pihak yang terkait, khususnya Universitas Katolik Musi Charitas untuk meningkatkan kualitas perkuliahan online.

\section{METODE PENELITIAN}

Penelitian ini merupakan penelitian kualitatif deskriptif. Di dalam penelitian ini, peneliti mendeskripsikan hasil penelitiannya dari hasil dokumentasi, observasi, dan wawancara. Kegiatan dokumentasi, observasi, dan wawancara dilakukan terhadap subyek penelitian, yang dipilih secara purposive.

Populasi dari penelitian ini adalah mahasiswa Program Studi PGSD Universitas Katolik Musi Charitas (UKMC), semester III. Mereka merupakan peserta kuliah 
Pembelajaran Matematika Kelas Tinggi, pada tahun pelajaran 2020/2021. Adapun rincian distribusi populasi berdasarkan jenis kelamin, disajikan pada Tabel 1.

Tabel 1. Distribusi Populasi Penelitian menurut Jenis Kelamin

\begin{tabular}{cccc}
\hline Kelas & Laki-laki & Perempuan & Jumlah \\
\hline PG 101 & 8 & 23 & 31 \\
PG 301 & 4 & 26 & 30 \\
PG 501 & 5 & 23 & 28 \\
PG 701 & 6 & 10 & 16 \\
\hline Total & 23 & 82 & 105 \\
\hline
\end{tabular}

Pengambilan sampel dilaksanakan dengan menggunakan metode non probability sampling. Sample merupakan mahasiswa dalam satu rombongan belajar, yang dipilih dari populasi mahasiswa secara purposive dari 4 (empat) kelas penyusun polulasi. Purposive sampling adalah metode pengambilan sampel secara sengaja dengan menggunakan suatu kriteria tertentu, sesuai dengan tujuan penelitian (Sugiyono, 2015). Kriteria yang digunakan dalam pemilihan ini adalah mahasiswa peserta kuliah online dengan persentase kehadiran tertinggi.

Kelas yang terpilih sebagai sample penelitian adalah kelas PG 301, sehingga distribusi sampel berdasarkan jenis kelamin disajikan pada Tabel 2.

Tabel 2. Distribusi Sampel Penelitian menurut Jenis Kelamin

\begin{tabular}{cccc}
\hline Kelas & Laki-laki & Perempuan & Jumlah \\
\hline PG 301 & 4 & 26 & 30 \\
\hline Total & 4 & 26 & 30 \\
\hline
\end{tabular}

Berdasarkan Tabel 2, diketahui bahwa jumlah sampel berjenis kelamin perempuan lebih banyak dari yang berjenis kelamin laki-laki. Keadaan tersebut bersesuaian dengan proporsi jenis kelamin mahasiswa yang mengontrak mata kuliah Pembelajaran Matematika Kelas Tinggi secara keseluruhan. Hal ini sesuai dengan kriteria utama dalam penentuan sample, dimana sampel merupakan representasi dari populasi. Sampel yang baik menurut (Sugiyono, 2015), adalah kumpulan individu yang memiliki karakteristik 
yang sama dengan karakteristik populasi.

Pengumpulan data dilakukan dalam tiga tahapan, dengan menggunakan tiga teknik pengumpulan data, yaitu dokumentasi, observasi, dan wawancara. Dokumentasi bertujuan untuk memperoleh informasi tentang pelaksanaan perkuliahan online pada mata kuliah Pembelajaran Matematika Kelas Tinggi. Dokumentasi proses pembelajaran diperoleh berupa screenshoot dari video conference, yang menggunakan zoom meeting. Observasi bertujuan untuk memperoleh informasi yang lebih detail tentang proses perkuliahan. Selanjutnya peneliti melakukan wawancara untuk mengetahui jenis platform pembelajaran online yang digunakan dan respon mahasiswa terhadap aktivitas perkuliahan online. Jumlah pertanyaan wawancara adalah sebanyak 10 item, yang disampaikan secara online kepada mahasiswa menggunakan google form.

Data yang diperoleh dari hasil dokumentasi, observasi, dan wawancara dianalisis dengan menggunakan metode statistik deskriptif, dan kemudian disajikan dalam bentuk diagram. Data hasil analisis tersebut kemudian dideskripsikan dalam bentuk narasi. Penyusunan narasi dalam penelitian ini bertujuan untuk mempermudah di dalam mencapai tujuan penelitian. Narasi merupakan informasi tentang respon mahasiswa terhadap aktivitas perkuliahan matematika secara keseluruhan.

\section{HASIL DAN PEMBAHASAN}

Hasil penelitian tentang respon mahasiswa terhadap perkuliahan online pada pembelajaran matematika kelas tinggi di UKMC, disajikan dalam dua aspek, yaitu platform perkuliahan online dan proses perkuliahan online. Secara terperinci kedua aspek tersebut diuraikan berikut ini.

\section{Platform perkuliahan online dalam pembelajaran Matematika}

Perkuliahan matematika kelas tinggi di UKMC dilaksanakan secara online selama masa Pandemi COVID-19, dengan memanfaatkan beberapa jenis platform pembelajaran online. Salah satu jenis platform yang digunakan adalah zoom meeting, sebagaimana tampak pada Gambar 1. 
Journal of Honai Math, Vol. 4, No. 1, pp. 67-84, April 2021

Lisnani \& Tanujaya, Respon Mahasiswa Terhadap Perkuliahan Online ...

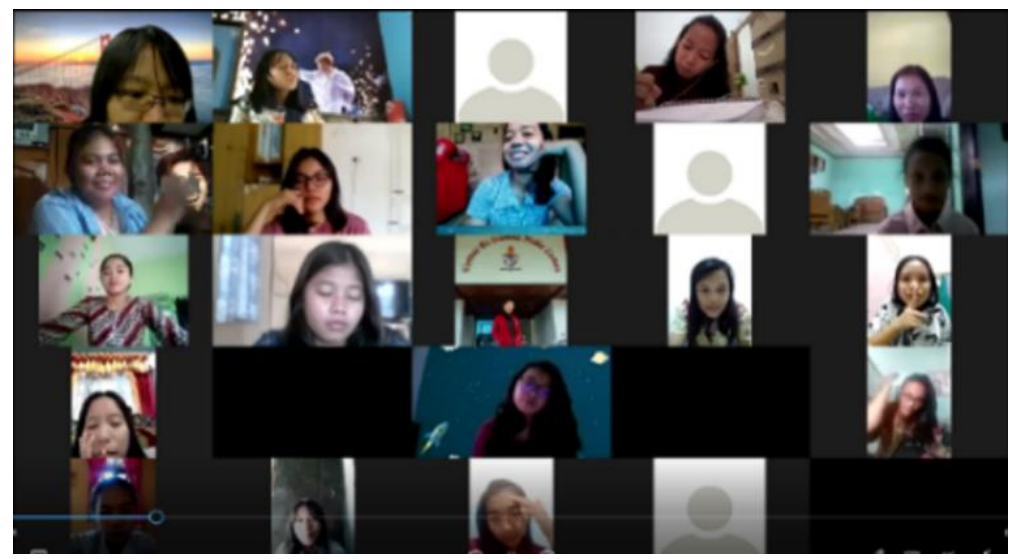

Gambar 1. Perkuliahan matematika secara online menggunakan zoom meeting

Gambar 1 menyajikan informasi tentang kegiatan perkuliahan matematika yang dilaksanakan menggunakan zoom meeting. Selain dengan zoom meeting, terdapat beberapa platform pembelajaran online yang digunakan selama pelaksanaan perkuliahan. Jenis-jenis platform Jenis-jenis platform yang digunakan diperoleh dari hasil wawancara dengan mahasiswa, sebagaimana disajikan pada Gambar 2.

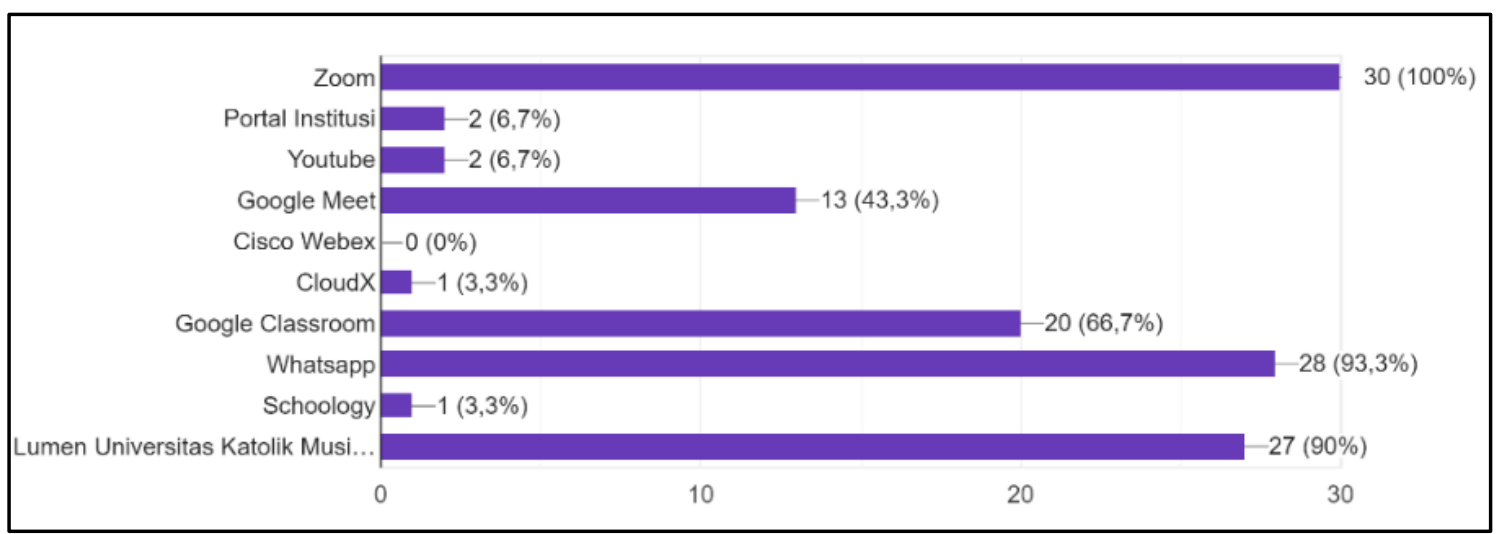

Gambar 2. Persentase penggunaan platform online dalam perkuliahan

Berdasarkan Gambar 2, tampak bahwa terdapat 4 (empat) jenis platform pembelajaran online yang dominan digunakan dalam perkuliahan matematika di UKMC. Hal ini menunjukkan bahwa empat jenis platform online, yaitu: Zoom meeting, WhatsApp, Lumen Universitas, dan Google Classroom, merupakan platform yang menjadi pilihan utama dalam perkuliahan. Terdapat beberapa platform lainnya yang juga digunakan dalam pembelajaran, seperti Google meet, Youtube dan CloudX, namun dalam frekuensi yang rendah. 
Beragamnya Platform perkuliahan online yang digunakan dosen, menunjukkan bahwa dosen dan mahasiswa mempunyai banyak pilihan dalam pelaksanaan perkuliahan. Selain itu, banyaknya jenis yang digunakan tersebut juga menunjukkan bahwa masih terdapat berbagai kendala dalam pemanfaatannya untuk aktivitas perkuliahan. Dengan kata lain, belum ada platform pembelajaran online yang lengkap dan memenuhi seluruh kebutuhan sebagai sarana perkulihan online.

Beragamnya jenis Platform yang digunakan dosen dalam pembelajaran, juga berdampak pada jenis Platform yang paling disukai mahasiswa selama kuliah online di masa Pandemi COVID-19, sebagaimana disajikan pada Gambar 3.

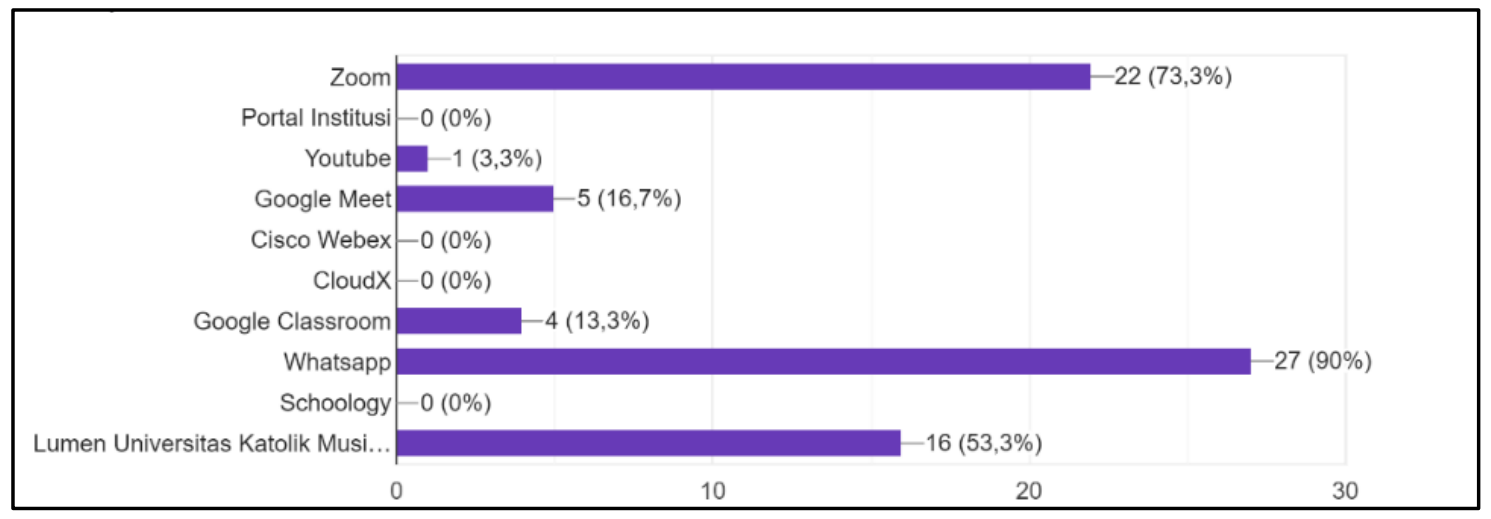

Gambar 3. Platform pembelajaran online yang disukai mahasiswa

Pada Gambar 3, tampak bahwa terdapat 3 (tiga) platform pembelajaran online yang paling disukai mahasiswa, yaitu WhatsApp, Zoom dan Lumen Universitas. Alasan utama mahasiswa menyukai platform tersebut adalah berhubungan dengan kepraktisan. Beberapa alasan lain mahasiswa menyukai suatu Platform pembelajaran online, disajikan pada Gambar 4.

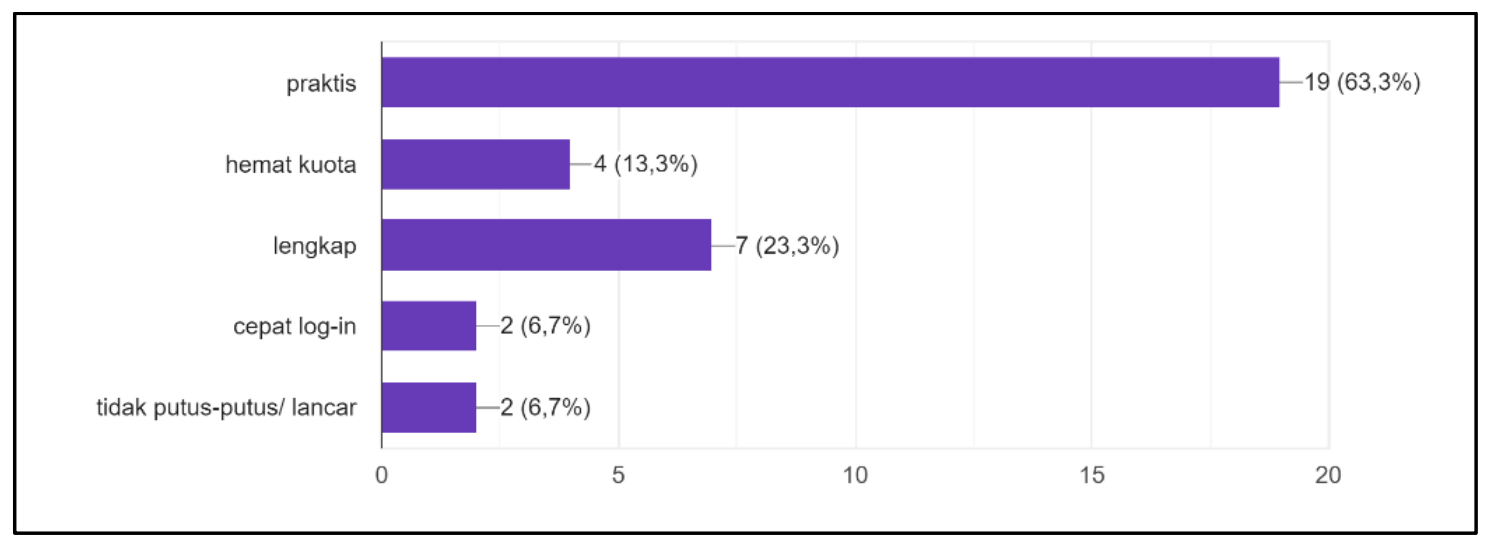

Gambar 4. Alasan mahasiswa memilih platform pembelajaran online 
Berdasarkan Gambar 4, tampak bahwa mahasiswa mendambakan Platform pembelajaran online yang sederhana tetapi memiliki fitur yang lengkap, sehingga mudah digunakan. Hal ini bersesuaian dengan pilihan mahasiswa yang cenderung memilih WhatsApp sebagai platform yang paling disukai, sebagaimana tampak pada Gambar 3. WhatsApp merupakan aplikasi yang tidak dirancang untuk pembelajaran sehingga mempunyai keterbatasan jika digunakan untuk perkuliahan, tetapi berpotensi untuk digunakan sebagai sarana pembelajaran. Librero et al., (2007) menjelaskan bahwa telepon seluler tidak dirancang untuk digunakan dalam dunia pendidikan, tetapi dapat digunakan sebagai sarana pembelajaran. Dosen harus mampu mengeksplorasi potensi telepon seluler, khususnya aplikasi WhatsApp sebagai perangkat penting dalam pelaksanaan perkuliahan.

Lebih lanjut terdapat beberapa kendala yang dihadapi mahasiswa selama proses perkuliahan online. Kendala utama yang dihadapi mahasiswa selama perkuliahan matematika yang dilaksanakan secara online adalah kualitas sinyal internet dan kesulitan dalam memahami materi. Beberapa kendala yang hadapi mahasiswa, tampak pada diagram sebagaimana disajikan pada Gambar 5.

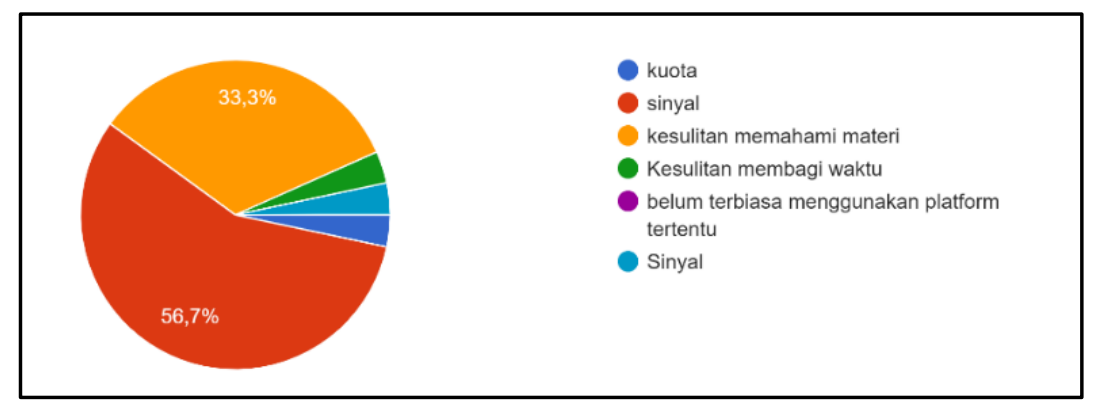

Gambar 5. Kendala yang dihadapi mahasiswa selama proses kuliah online

Pada Gambar 5, tampak bahwa kualitas sinyal internet merupakan permasalahan utama mahasiswa yang mengikuti kuliah Pembelajaran Matematika Kelas Tinggi. Di lain pihak, kualitas internet merupakan persyaratan pertama dan utama agar perkuliahan online dapat berlangsung dengan baik. Keadaan ini hampir merata di seluruh wilayah Indonesia. Berdasarkan hasil penelitiannya, Tanujaya, et al. (2021), menyatakan bahwa hal pertama dan utama yang perlu dilakukan pemerintah Indonesia untuk meningkatkan kualitas pembelajaran online adalah melalui peningkatan akses internet ke seluruh pelosok tanah air. 


\section{Proses Perkuliahan Matematika}

Dalam rangka untuk mempertahankan kualitas perkuliahan Pembelajaran Matematika Kelas Tinggi, maka dosen melaksanakan perkuliahan online dengan tahapan yang sama seperti prosedur perkuliahan tatap muka. Perkuliahan ini diawali dengan pembukaan kuliah, yang meliputi penyajian kontrak kuliah dan penjelasan tentang silabus mata kuliah. Kedua tahapan dalam perkuliahan tersebut, disajikan pada Gambar 6 dan Gambar 7.

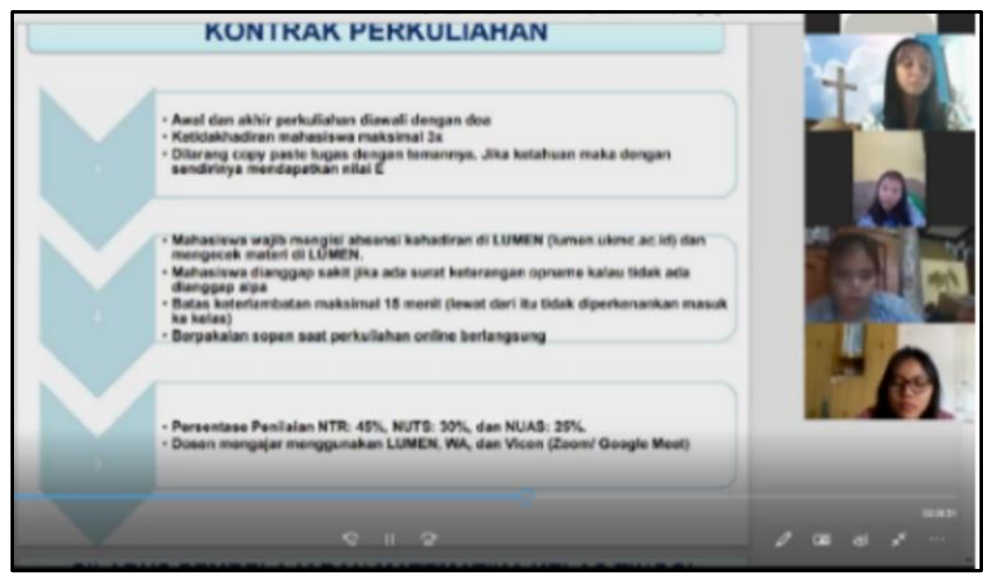

Gambar 6. Dosen menyampaikan kontrak perkuliahan

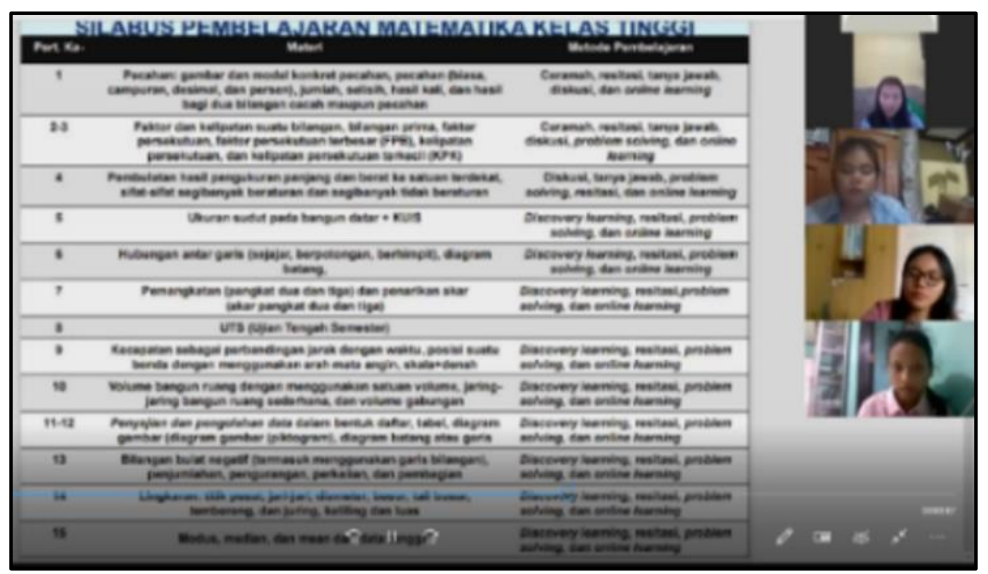

Gambar 7. Dosen menyampaikan silabus perkuliahan

Lebih lanjut, sewaktu menjelaskan materi perkuliahan, dosen menggunakan bendabenda konkret dan gambar sebagai media atau peraga. Kedua pendekatan tersebut dilakukan agar mahasiswa lebih mudah memahami konsep yang diajarkan, sebagaimana disajikan pada Gambar 8 dan Gambar 9. 
Journal of Honai Math, Vol. 4, No. 1, pp. 67-84, April 2021

Lisnani \& Tanujaya, Respon Mahasiswa Terhadap Perkuliahan Online ...

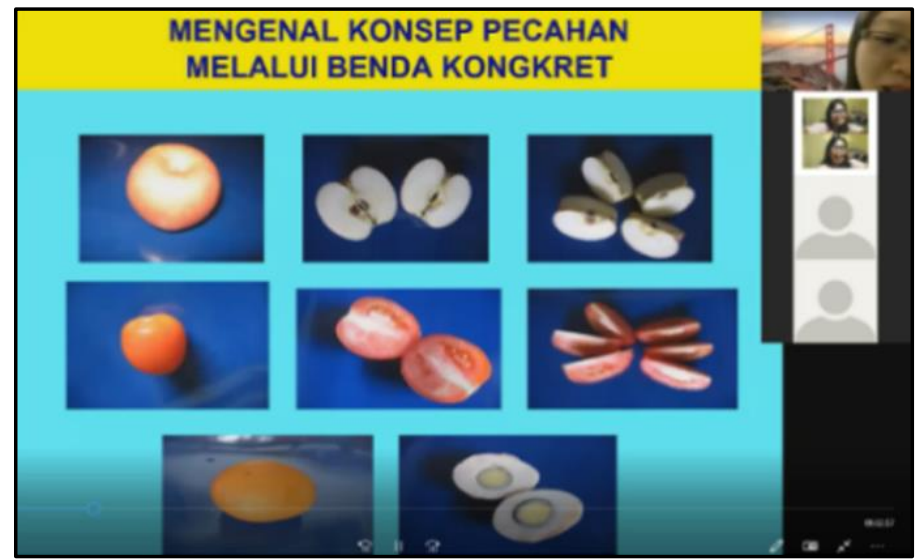

Gambar 8. Dosen menjelaskan konsep pecahan melalui benda konkret

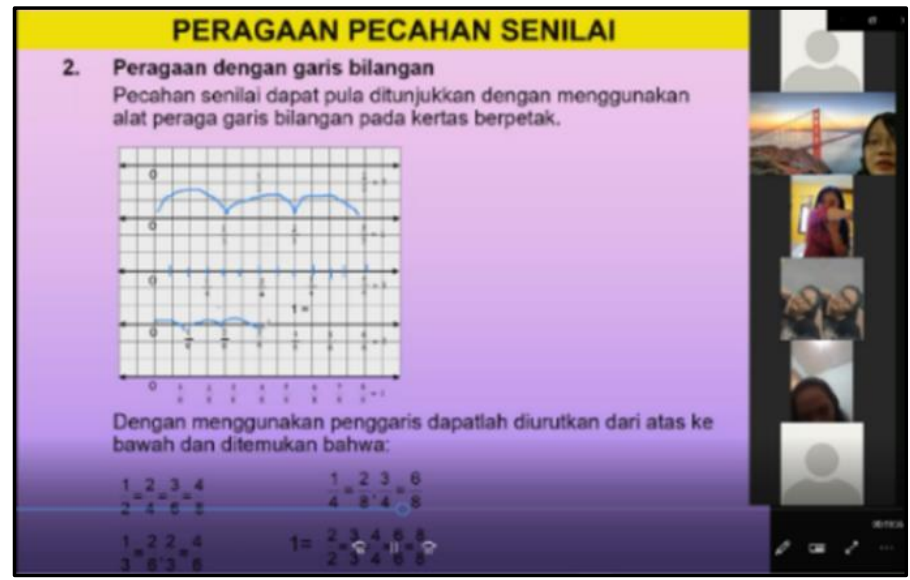

Gambar 9. Dosen menjelaskan peragaan pecahan senilai menggunakan huion

Selain menjelaskan materi kuliah, dosen juga memberikan tugas kepada mahasiswa. Pemberian tugas bertujuan untuk dosen dapat melakukan penilaian yang otentik terhadap hasil belajar mahasiswa. Penilaian hasil belajar menurut Tanujaya (2017), merupakan proses mengumpulkan informasi tentang pemahaman seorang mahasiswa pada suatu konsep tertentu, yang salah satu tujuannya adalah untuk meningkatkan hasil belajar. Frekuensi dosen memberikan tugas selama perkuliahan menurut mahasiswa, disajikan pada Gambar 10.

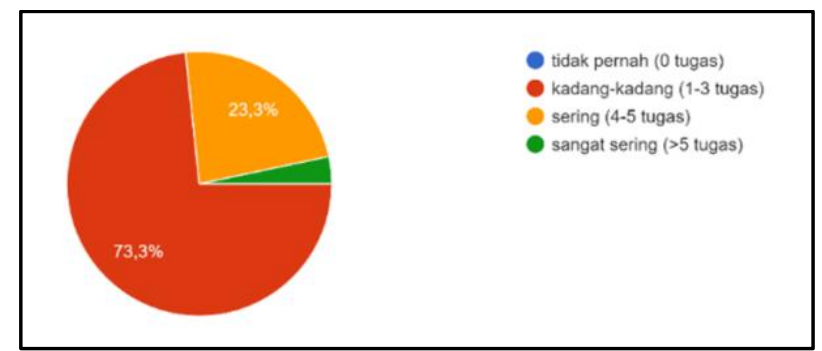

Gambar 10. Frekuensi pemberian tugas pada perkuliahan. 
Lebih lanjut, pada waktu ditanyakan, apakah terdapat perbedaan cara dosen menyampaikan materi Pembelajaran Matematika Kelas Tinggi, pada perkuliahan online dan perkuliahan tatap muka. Seluruh mahasiswa setuju bahwa keduanya tidak berbeda. Respon mahasiswa terhadap pertanyaan tersebut ditampilkan pada Gambar 11.

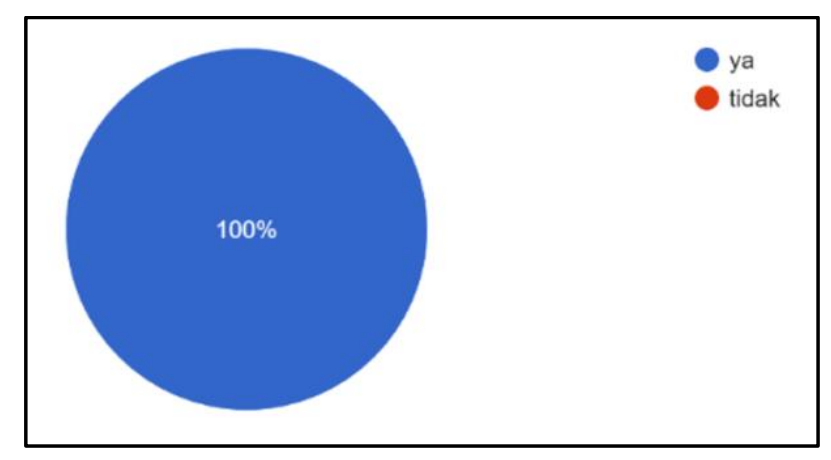

Gambar 11. Kesamaan penyampaikan materi perkuliahan online dan tatap muka

Namun demikian, hal berbeda tampak pada pemahaman mahasiswa terhadap materi perkuliahan yang disampaikan dosen selama proses perkuliahan online. Sebagian besar mahasiswa hanya menyatakan cukup memahami materi yang disampaikan dosen sebagaimana tampak pada Gambar 12. Hal ini mengimplikasikan bahwa perkuliahan online masih masih belum dapat dimanfaatkan secara maksimal oleh mahasiswa.

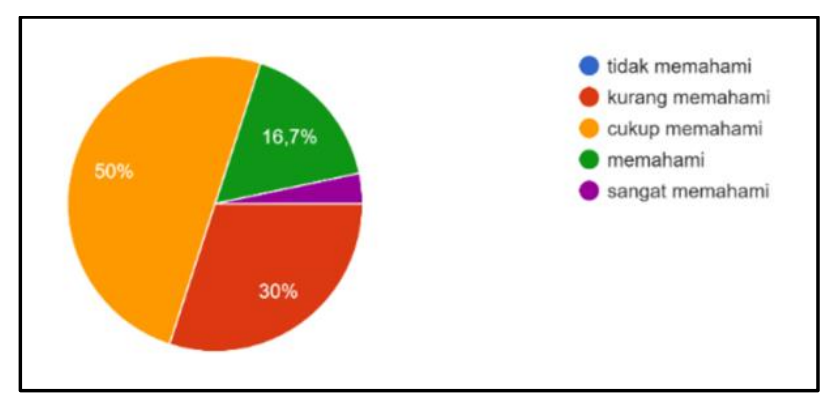

Gambar 12. Pemahaman mahasiswa terhadap materi perkuliahan

Lebih lanjut pada waktu ditanyakan tentang persentase pemahaman mereka terhadap materi perkuliahan, sebagian besar mahasiswa memiliki persentase pemahaman terhadap materi yang disampaikan dosen sebesar $51-75 \%$. Secara detail persentase pemahaman mahasiswa terhadap materi perkuliahan disajikan pada Gambar 13. 


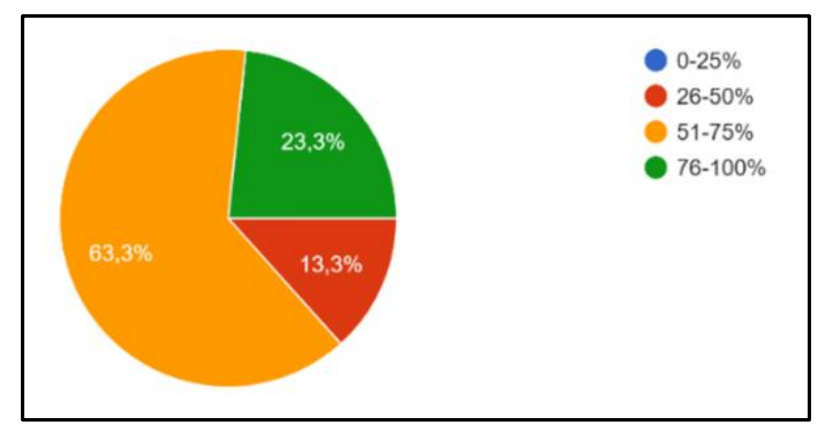

Gambar 13. Persentase pemahaman mahasiswa terhadap materi perkuliahan

Gambar 13 menjelaskan bahwa persentase mahasiswa yang dapat memahami materi perkuliahan tidak terlalu besar, yaitu hanya sekitar 23,3\%. Rendahnya angka tersebut diduga disebabkan karena beberapa faktor, salah satu diantaranya adalah rendahnya interaksi antara dosen dan mahasiswa selama perkuliahan online. Menurut para mahasiswa, mereka menghadapi berbagai kendala pada waktu ingin menyampaikan pertanyaan. Mereka tidak bebas bertanya sebagaimana pada perkuliahan tatap muka. Keadaan ini menyebakan dosen tidak mengetahui apa yang telah diketahui dan belum diketahui oleh mahasiswa, secara lebih akurat.

Tanujaya, et al. (2021), menyatakan bahwa salah satu kendala dalam pembelajaran online adalah rendahnya interaksi antara dosen dan mahasiswa. Dalam upaya untuk meningkatkan kualitas perkuliahan, maka salah satu upaya yang dapat dilakukan adalah dosen mewajibkan mahasiswa untuk mengerjakan tugas dalam bentuk video. Video tersebut berisi tentang tahapan atau prosedur yang dilakukan mahasiswa sewaktu menyelesaikan suatu permasalahan.

Selain itu, rendahnya pemahaman mahasiswa terhadap materi perkuliahan juga disebabkan karena rendahnya tingkat kesukaan mahasiswa terhadap perkuliahan online. Mayoritas mahasiswa yang menempuh mata kuliah Pembelajaran Matematika Kelas Tinggi menyatakan tidak menyukai perkuliahan online. Persentase mahasiswa yang tidak menyukai kuliah online sangat banyak, sebagaimana tampak Gambar 14. 


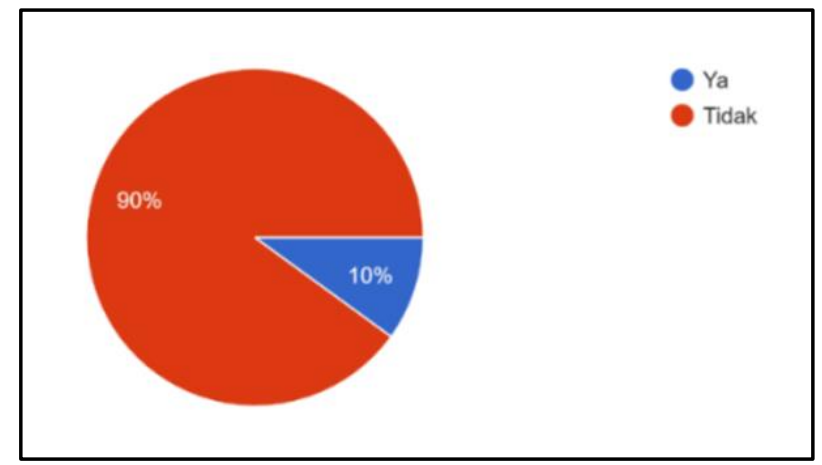

Gambar 14. Kesukaan mahasiswa terhadap perkuliahan online

Terdapat beberapa alasan mengapa mahasiswa tidak menyukai perkuliahan online. Dua alasan utama para mahasiswa tidak menyukai perkuliahan online, yaitu: ketergantungan terhadap kualitas sinyal internet, dan kesulitan memahami materi kuliah. Beberapa alasan lainnya, disajikan pada Gambar 15.

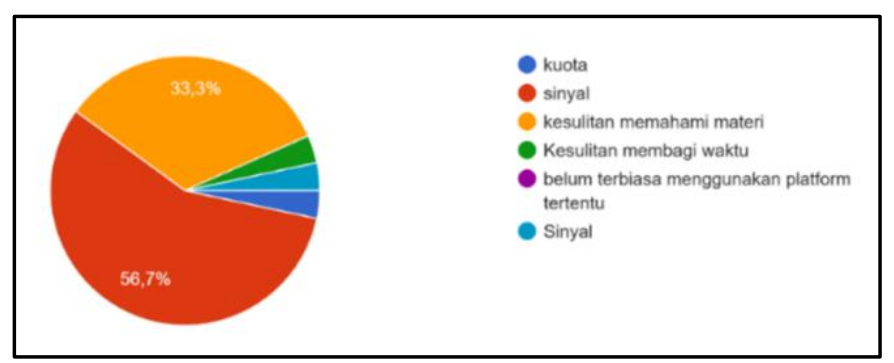

Gambar 15. Alasan mahasiswa tidak menyukai perkuliahan online

Gambar 15 mengimplikasikan bahwa alasan utama mahasiswa tidak menyukai perkuliahan online adalah keterbatasan melakukan interaksi, baik dengan dosen maupun dengan mahasiswa lain. Diskusi dengan dosen dan teman sangat terbatas tergantung pada kuota data internet yang dimiliki. Hal ini sesuai dengan pendapat Duran (2020), yang menyatakan bahwa perkuliahan online cenderung bersifat satu arah. Dosen menyampaikan materi kuliah dan mahasiswa hanya mendengar.

Lebih lanjut, kualitas signal internet yang tidak stabil, baik yang disebabkan oleh gangguan listrik, cuaca, maupun keterbatasan kuota internet, juga merupakan kendala lainnya yang menyebabkan aktivitas perkuliahan tidak dapat berlangsung dengan maksimal. Signal internet yang tidak stabil menyebabkan mahasiswa tidak dapat mengikuti perkuliahan secara kontinyu, tidak dapat mengikuti kuliah sesuai jadwal, dan sering "dikeluarkan" dari kelas online. Hal ini menyebabkan mahasiswa frustasi dan 
depresi, yang berdampak terhadap tingkat pemahaman terhadap materi kuliah.

Keterbatasan waktu untuk mengerjakan tugas, dan waktu untuk mengumpulkan tugas juga merupakan kendala lainnya dari perkuliahan online. Jadwal kuliah yang tersusun secara berkesinambungan menyebabkan tugas yang diberikan dosen tidak dapat dikerjakan secara langsung. Di lain pihak, setelah tugas dikerjakan terkadang mahasiswa juga tidak dapat secara langsung mengumpulkannya karena kualitas jaringan internet yang tidak mendukung.

Permasalahan lainnya yang dihadapi mahasiswa selama perkuliahan online adalah suasana di tempat tinggal yang tidak mendukung. Kebisingan yang disebabkan oleh anggota keluarga lain, kendaraan bermotor, dan gangguan lainnya, juga merupakan kendala dalam perkuliahan online. Tidak semua mahasiswa memiliki ruangan khusus yang dapat digunakan untuk mengikuti perkuliahan online. Tempat yang digunakan untuk mengikuti perkuliahan online terkadang harus berbagi dengan orang tua, kakak, adik, teman, dan anggota keluarga lainnya. Keadaan tersebut menyebabkan mahasiswa tidak berkonsentrasi penuh dalam mengikuti perkuliahan online.

Namun demikian, perkuliahan online merupakan salah satu alternatif yang dapat dilakukan agar perkuliahan dapat berlangsung pada masa pandemic Covid-19 ini. Dosen dan mahasiswa harus mampu beradaptasi dan berkreasi agar perkuliahan dapat berlangsung dengan baik. Menurut Agnoletto and Queiroz (2020), dalam penelitiannya yang berjudul "COVID-19 and the challenge in education" menyatakan bahwa pembelajaran online bukan merupakan sesuatu yang sederhana. Selalu ada permasalahan yang mengharuskan kita beradaptasi atau mencari solusi untuk mengatasinya.

Dengan demikian, dosen dengan bantuan universitas harus mampu meningkatkan kapasistas dan kapabilitasnya sehingga perkuliahan online dapat berlangsung dengan baik. Dosen harus kreatif pada waktu menyajikan materi kuliah, pemberian tugas, maupun pada waktu melakukan penilaian hasil kerja mahasiswa. Salah satu pendekatan yang dapat dilakukan adalah menerapkan model pembelajaran blended learning dengan tetap memperhatikan protokol kesehatan dari pemerintah. Sukarno (2014) menyatakan bahwa blended learning merupakan model pembelajaran yang sudah dikenal dan diterapkan di Indonesia. Dengan demikian, dosen lebih mudah mengadaptasikannya menjadi model pembelajaran yang dapat diterapkan di masa pandemi ini.

Di lain pihak, mahasiswa juga harus mampu beradaptasi dengan perkuliahan online. 
Mahasiswa juga harus aktif dan kreatif pada waktu mengikuti perkuliahan matematika secara online. Singkatnya, semua pihak harus berubah termasuk mahasiswa, terutama cara pandang mereka tentang perkuliahan online. Hal ini sesuai dengan pendapat Daniel (2020), yang menyatakan bahwa selama pandemi COVID-19 ttelah erjadi perubahan signifikan di bidang pendidikan terkait kebutuhan dan cara pandang semua yang terlibat dalam dunia Pendidikan. Tanpa perubahan cara pandang, maka perkuliahan online tidak dapat berlangsung sebagaimana diharapkan.

\section{KESIMPULAN}

Perkuliahan matematika pada Pembelajaran Matematika Kelas Tinggi secara online dilaksanakan dengan menggunakan beragam jenis Platform pembelajaran online, antara lain: Zoom meeting, WhatsApp, Lumen universitas, dan Google meet. Penggunaan beberapa jenis Platform pada dasarnya bertujuan untuk memaksimalkan fungsi setiap Platform. Agar pembelajaran dapat berlangsung dengan baik, maka perkuliahan online dilaksanakan dengan prosedur yang tidak berbeda dengan perkuliahan tatap muka, namun mahasiswa kurang menyukainya. Permasalahan utamanya adalah rendahnya kualitas interaksi dalam perkuliahan, baik antara dosen dan mahasiswa, maupun interaksi antar mahasiswa. Terdapat dua penyebab dari permasalahan ini, yaitu kualitas jaringan internet yang tidak stabil dan kesulitan memahami materi kuliah, selain suasana tempat belajar mahasiswa yang tidak kondusif.

\section{REFERENCES}

Agnoletto, R., \& Queiroz, V. (2020). COVID-19 and the Challenges in Education. CESTBulletin, 5(2), 1-2.

Aldiab, A., Chowdhury, H., Kootsookos, A., Alam, F., \& Allhibi, H. (2018). Utilization of Learning Management Systems (LMSs) in Higher Education: A Case Review for Saudi Arabia. Energy Procedia, 160, 731-737.

Duran, L. M. S. (2020). Distance learners' Experiences of Silence Online: A Phenomenological Inquiry. International Review of Research in Open and Distributed Learning, 21(1), 82-99. https://doi.org/10.19173/irrodl.v20i5.4538.

Erin \& Maharani, A. (2018). Persepsi Mahasiswa Pendidikan Matematika Terhadap Perkuliahan Online. Mosharafa: Jurnal Pendidikan Matematika, 7(3), 337-344. 
Firman \& Rahman, S. R. (2020). Pembelajaran Online di Tengah Pandemi Covid-19. Indonesian Journal of Educational Science (IJES), 2(2), 81-89.

Ihsanuddin. (2020). Fakta Lengkap Kasus Pertama Virus Corona di Indonesia. https://nasional.kompas.com/read/2020/03/03/06314981/fakta-lengkap-kasuspertama-virus-corona-di-indonesia?page $=$ all .

Kemdikbud. (2020). Surat Edaran Nomor 3 Tahun 2020 tentang Pencegahan COVID-19 pada Satuan Pendidikan. Kementerian Pendidikan dan Kebudayaan Republik Indonesia: Jakarta

Khairanisyam, N. (2020). Belajar Online di Tengah Pandemi Covid-19. https://www.kompasiana.com/nksyam/5e9b314ed541df0337573152/belajaronline-ditengah-pandemi-covid-19?page $=1$.

Khoza, S. B. (2014). Is chemistry everything to engineering students? Let their experiences talk. South African Journal of Higher Education, 28(2), 501-513.

Librero, F., Ramos, A. J., Ranga, A. I., Trinova, J., \& Lambert, D. (2007). Uses of the cell phone for education in the Philippines and Mongolia. Distance Education, 28(2), 231-224. https://doi.org/10.1080/01587910701439266

Mc.Gee, E., \& Poojary, P. (2020). Exploring Blended Learning Relationships in Higher Education Using A Systems-Based Framework. Turkish Online Journal of Distance Education, 21(4), 1-13.

Mtebe, J. S. (2015). Learning Management System Success: Increasing Learning Management System Usage in Higher Education in sub-Saharan Africa. International Journal of Education and Development using Information and Communication Technology (IJEDIC), 11(2), 51-64.

Shamsuddin, N., \& Kaur, J. (2020). Students' Learning Style and Its Effect on Blended Learning, Does It Matter? International Journal of Evaluation and Research in Education (IJERE), 9(1), 195-202. https://doi.org/10.11591/ijere.v9i1.20422.

Sugiyono. (2015). Metode Penelitian Pendidikan: Pendekatan Kuantitatif, Kualitatif, dan $R \& D$. Bandung: Alfabeta.

Sukarno. (2014). Peningkatan Kualitas Perkuliahan Melalui Penerapan Model Blended Learning dengan Aplikasi Learning Management System pada Mahasiswa Program Sarjana Kependidikan Bagi Guru dalam Jabatan. Jurnal Pendidikan dan Pembelajaran, 21, 61-70. 
Tanujaya, B, (2017). Application of Assessment as Learning in Mathematics Instruction. Advances in Social Science, Education, and Humanities Research, 100, 140-145.

Tanujaya, B., Prahmana, R.C.I., \& Mumu, J. (2021). The Mathematics Instruction in Rural Area during the Pandemic Era: Problems and Solutions. Mathematics Teaching Research Journal, 13(1), 3-15.

UNESCO. (2020). 290 Million Students Out of School Due to COVID-19: UNESCO Releases First Global Numbers and Mobilizes Response. Diakses 13 April 2020, https://en.unesco.org/news/290million-students-out-school-due-covid-19unescoreleases-first-global-numbers-andmobilizes.

UNESCO. (2020). COVID-19 Educational Disruption and Response. Diakses 13 April 2020, https://en.unesco.org/themes/educationemergencies/coronavirus-schoolclosures.

Widiyono, A. (2020). Efektifitas Perkuliahan Daring (Online) pada Mahasiswa PGSD di Saat Pandemi Covid 19. Jurnal Pendidikan, 8(2), 169-177. 